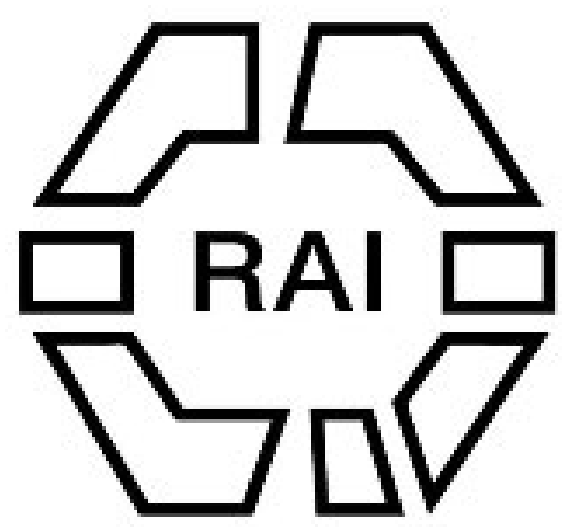

On Non-Sepulchral Rude Stone Monuments.

Author(s): M. J. Walhouse

Source: The Journal of the Anthropological Institute of Great Britain and Ireland, Vol. 7 (1878), pp. 21-43

Published by: Royal Anthropological Institute of Great Britain and Ireland

Stable URL: http://www.jstor.org/stable/2840932

Accessed: 15/06/2014 22:06

Your use of the JSTOR archive indicates your acceptance of the Terms \& Conditions of Use, available at http://www.jstor.org/page/info/about/policies/terms.jsp

JSTOR is a not-for-profit service that helps scholars, researchers, and students discover, use, and build upon a wide range of content in a trusted digital archive. We use information technology and tools to increase productivity and facilitate new forms of scholarship. For more information about JSTOR, please contact support@jstor.org. 


\section{For the Library.}

From the Society. - Jahrbuch der K. K. Geologischen Reichsanstalt. Vol. XXVI, No. 3; Verhandlungen, do. Nos. 11-13.

From the SocieTr.-Mittheilungen der Anthropologischen Gesellschaft in Wien. Vol. VI, No. 5.

From the Association-Report of the Geologists Association for 1876.

From the Academy.-Atti della R. Accademia dei Lincei Anno. CCLXXIV. Vol. I, Nos. 1 and 2.

From the Academy.-Bulletin de l'Académie Imperiale des Sciences de St. Petersbourg. Vol. XXII, No. 4; Vol. XXIII, No. 1.

From the EdiTor - Matériaux pour l'Histoire de l'Homme.

From the Society.-Annuaire de la Société d'Ethnographie, 1877.

From the Edror.--Revae Scientifique, Nos. 34 and 35. 1877.

From the EdiroR.-Nature (to date).

Miss Buckland presented a digging stone from the Cape of Good Hope, for which thanks were returned.

Mr. M. J. Walhouse then read a paper entitled-

On Non-Sepulchral Rude Stone Monuments. By M. J. Walhouse, F.R.A.S.

Even in the earlier part of the present century, many fanciful theories were current respecting the nature and intention of megalithic monuments, cromlechs, stone circles, and the like; and much ingenious speculation was wasted in tracing the coils and windings of serpent-temples in the scattered stones of Wiltshire and Somersetshire, or, as some would have it, in identifying them with Temples of the Sun or Bardic Circles. The Druids were seen everywhere; "rock gnomons" indicated their knowledge of astronomy, "rock basons" and "rocking stones," often natural, were ascribed to their skill in mechanics, and cromlechs were held to be the "altars" on which they celebrated their bloody rites; while any chance marks on their surfaces were channels to drain off the blood of victims, and holes or chinks in the slabs were magical openings, through which auguries were drawn from their dying groans and cries. When search succeeded theory, the spade proved the revealer of the secrets of such monuments, and the incontrovertible dispeller of Druidical and Dracontian dreams; and their intention was shown to be sepulchral in such an immense majority of instances that theory swung perhaps too absolutely to the other extreme, and refused to see in them any other nature or purpose. It is desired in this paper to offer a few remarks upon some megalithic remains that have come under my observation in India and else- 
where, which may be ascribed to purposes other than sepulchral, and in many instances are connected with existing worship and observances. To begin with the sinplest of monuments, the heap of stones or cairn-though usually sepulchral and piled over a tomb-it is occasionally rather memorial or ceremonial. Twice in India in wild mountain-passes I have seen cairns raised on spots where men had been carried away by tigers. Passers-by added stones to the heap, with the idea of propitiating the angry ghost of the unlucky man, which was believed to haunt the spot, and guide the tiger in its attacks on wayfarers. Such heaps are sometimes also raised at spots on the plains where travellers have died suddenly, from sickness, or in any unusual way, and where stones are scarce or have failed, bits of rag are tied to a neighbouring thorn-bush, after a custom that appears to prevail from China to Ireland, prompted possibly by an idea of propitiation. Though the old Testament records three instances of cairn-burial, when Absalom, and Achan, and the King of Ai were laid under " a very great heap of stones," the earliest mention of cairns is as boundary-marks.* In the agreement betwreen Jacob and Laban recorded in the 31st chapter of Genesis, they gathered stones and made a heap expressly called a " heap of witness," on which they sat and did eat, as a ceremonial compact, and declared the heap to be a witness between them, that neither would pass over it into the territory of the other. The late Professor H. H. Wilson has translated a hymn from the Rig Veda, addressed in the earlier verses to Mrityu or Death, and in the last to the Pitris or Manes, the 4th verse of which is remarkable as containing the earliest, and, so far as I know, the only Sanskrit allusion to rude stone monuments, and also as seeming to intimate a purpose not sepulchral, but propitiatory, and, as in Genesis, boundary-marking. "I place this circle of stones for the living; on this account, that no other may go beyond it. May they live a hundred years, keeping death at a distance by this heap." In Livingstone's Expedition to the Zambesi, at page 229, there is an account rather curiously recalling the transaction between Laban and Jacob. On passing a large stone cairn in the country of the Batoka, the guide related that once upon a time a tribe was going to fight with another tribe, but sitting down there consulted and agreed that it would be more like men to raise this heap of stones as their protest against the wrong the other tribe had done them, which,

* In old Greece heaps of stones, called Hermaia, were commonly raised at crossways and on boundaries. They were sacred to Hermes, and each passer-by threw a stone on as an offering to the god. Homer ("Odyssey," xvi, 471) mentions such a heap near Ithaca. Strabo saw similar heaps on the roads in Egypt (xvii, p. 818) 
having accomplished, they returned quietly home. And again in his Last Journals, page 90, "we passed two cairns this morning at the beginning of the very sensible descent to the lake. They are very common in all this Southern Africa in the passes of the mountains, and are meant to mark divisions of countries, perhaps burial-places, but the Waiyan who accompanied us thought that they were merely heaps of stone collected by some one making a garden. The cairns were placed just about the spot where the blue waters of Nyassa first came fairly into view." This recalls the cairn piled by the Ten Thousand where the Euxine burst into sight, and the army raised the memorable cry.

Closely akin to unsepulchral cairns must be the Mâni, or long heaps of stones that excite the surprise of travellers in Thibet and Tartary. The late Mr. C. Horne, of the Bengal Civil Service, F.L.S., F.R.A.S., \&c., who some years ago travelled over some of the highest Himalayan passes, wrote to me respecting them: "The Lama Tartars build long walls of loose stones, usually about 6 feet thick and 5 high; sometimes as at Nako, half a mile long. Every native passes them to his right; none seem to know why: hence there is a path worn on that side, and every one adds a stone; they must be the growth of centuries, every generation adding some yards. The heaps often have flag's stuck on them and scraps of paper, with some sacred writing, as also horns of ibex, wild sheep, goats, \&c., and round boulder-stones, inscribed with the Buddhist prayer in a circle, are often laid on the top. A great mystery attaches to them; none can explain their uses certainly; some say they are devotional, others that they were built on return from long journeys. The farthest object I saw in Tartary was a long double range of these walls." Mr. Wilson recently in his "Abode of Snow" mentions having passed hundreds of these Mâni on his journey, sometimes in the most desolate situations, and remarks that the prodigious number of them in so thinly peopled a country indicates an extraordinary waste of human energy. Mr. Horne also mentioned that single heaps of stones abounded everywhere, "existing on every hill-top and pass; some evidently of great antiquity; in some places they are called Thôr.* At the entrance of the province of Kurnawûr there is a large field of them, all set up by grateful hill-men returning safe from the plains. Another cause of them is the setting of boundary marks by petty chiefs in old times. Presents too

* The missionaries, Huc and Gabet, encountered similar large heaps on the great plateau in Chinese Tartary, there called Oboes, and stuck over with boughs on which strips of inscribed paper are hung. MM. Huc and Gabet say tho Tartars w orship the Spirit of the Mountuin at thrm. 
are sometimes given by wealthy people to erect stone heaps on apparently inaccessible peaks to commemorate their names. The highest I saw was on the Shatûl peak (17,000 feet), near Kurnawûr. The climber was paid 100 rupees by a rich merchant, but disappointed his employer, as the 'Thôr' is called by his, and not the merchant's, name. I never heard of people being buried under these heaps." The foregoing examples will suffice to show how cairns, both in ancient and modern times, may have had other than sepulchral purposes. The legend of Izdubar or Nimrod, between 2,000 and 3,000 B.C., in the Babylonian tablets, says of him, "He collected great stones; he piled up the great stones."

A brief reference will be sufficient to perhaps the most extraordinary and enigmatical groups of megalithic remains, the great assemblages of stones disposed in rows, avenues, and alignments in the neighbourhood of Carnac, in Britanny, and in England at Ashdown, in Berkshire, and in many places on the Dartmoor.

Somewhat analogous remains in the East have been described by the late Col. Meadows Taylor in Shôrapûr, a province of Hydrabad, in the Deccan. The secret of these monuments has not yet been certainly read. Mr. Fergusson's conjecture that they are the memorials of battle-fields seems as good as any that has been proposed, with reference at least to most; at any rate, there has been nothing discovered proving them to mark burialplaces. I find it, however, difficult to accept Mr. Fergusson's view that the long parallel lines of stones on the Dartmoor represents an army, or two armies, drawn up in battle-array. I have personally examined a considerable number of these strange narrow paths and found them in all sorts of places, in hollows on hill-sides, and running over the brows of hills. Many exist unnoticed amongst the fern and bushes of the rougher tracts, and hardly could denote battle-arrays. The avenues under Kes Tor, near Chagford, in particular, referred to by Mr. Fergusson ("Rude Stone Monuments," p. 56), as possibly representing a battle-array, which I carefully walked over last summer, did not appear to me to carry out the idea. The long double lines of stones starting from the "Long-stone," a tall menhir, bend round the sides of an eminence under the somewhat altar-shaped rocks of the Kes Tor, on the top of which a very large and regular rock-bason, till lately filled with and concealed by peat, has been discovered, and seem to stretch on, till disappearing, toward the great stone circle, indistinctly visible a long way below in a hollow on the other side of the Teign. These mysterious lines of stones would often recall processional paths were they not so narrow, beginning and ending so abruptly, ap- 
parently without purpose or direction, and at times in situations hard to reconcile with the idea: their meaning has not been penetrated, but they suggest nothing sepulchral.* In India the remains, apparently of this class, at Shahpûr, in the Shôrapûr principality, were considered by Col. Meadows Taylor more remarkable and interesting even than the cromlechs and stone circles which also abound in the neighbourhood and with which they are sometimes associated. Huge masses of granite are disposed in an exact parallelogram 400 feet by 260 , or sometimes in squares, enclosing similar figures of smaller rocks, and in the centre of some rises a tumulus, which excavation has shown to be sepulchral or possibly sacrificial. These squares are grouped together over large areas; the rocks composing the outer lines are from 7 to 10 feet long, nearly as broad, and from 4 to 7 feet high, and must have been brought from hills nearly two miles distant over a difficult surface; an undertaking impossible in that country at present. All the squares do not enlose tumuli; in one large group there are but two, but as cairns do accompany them in several instances, it would not be safe to assert that they could be other than appurtenances at least to sepulchres. As to the multitudinous groups of upright stones that so remarkably characterise the Kasia Hills bordering on Assam, Major Godwin-Austen, in a paper read before the Institute, has shown that they have no connection with funeral obsequies, but are memorials raised to propitiate the spirits of the deceased and to perpetuate their memories. Regular trilithons often occur amongst them, and it is remarkable that amongst another aboriginal tribe, the Santhals, in Bengal, a trilithon that must be a very striking monument is at this day an altogether devotional object. It is described at page 192 of Dr. Hunter's "Annals of Royal Bengal" as "three huge monoliths of gneiss of great beauty, two upright, the third laid across them. The stones are upwards of 12 feet in length, each weighing upwards of 7 tons, quadrilateral, 10 feet round, the horizontal stone kept in its place by a mortise or tenon. Origin unknown: worshipped by the Santhals at the West Gate of their Holy City in Bheerbloom."

Trilithons that must be not dissimilar to this have been described by Dr. Barth in the regions about Tripoli, in northern Africa. Two are figured at pages 411-12 of Fergusson's " Rude Stone Monuments." There is no reason to regard them as sepul-

* Since writing the above, I find that in the Appendix to vol. $i$ of the Journa] of this Institute, at page cxi, et seq., Mr. Spence Hardy has described these Dartmoor avenues, and thinks they may be "burial places for the honoured dead," whilst Dr. A. Campbell considered them to be "indisputable signs of cultiva. tion." All these so different opinions show that these rt mains are still enign. as. 
chral, and Dr. Barth, a competent observer, thinks them "evidently connected with the religious rites of the ancient inhabitants of these regions." And so it may be inferred was "the gigantic circle with huge upright stones, 15 feet high, and some with long blocks laid across," seen by Mr. Palgrave in the previously unknown wastes of central Arabia, of which, it is to be hoped, more maý be heard some day.*

Professor Max Müller remarks, "Children all over the world, if building houses with cards, will build cromlechs; and people all over the world, if the neighbourhood supplies large slabs of stone, will put three stones together to keep out the sun or the wind, and put a fourth stone on the top to keep out the rain ;" and whenever a people become led to form a rude image and reverence it, or regard a rough stone with superstitious ideas, it was in such a structure they may be supposed to have been impelled to place it. This was strongly borne in upon the mind on flrst seeing the small cromlech-temples used to-day by the people in some parts of Southern India. I had become fixed in the belief that all cromlech-like structures were sepulchral, till once on emerging from a wild mountain-pass on to the table-land of Mysore I saw by the wayside a primitive temple consisting of back and side slabs set on edge, with a covering slab laid over, the front open, a rude image of Hanumân within, and a few flowers strewn before it. The appropriateness of such a construetion, and the readiness with which it could be imagined and raised by a rude people in a wild locality, were at once obvious. I afterwards saw some more similar rude-stone temples always in unfrequented tracts. Of course these rustic shrines were not prehistoric, but their use and tradition may have come down from prehistoric times. $†$ Subsequently on the Shiarâi Hills, a fine mountain-range with a table-land of about 4,000 feet general elevation, in the district of Salem, midway between Madras and the Malabar coast, I found these temple-cromlechs in common use by the Malayâlies $=$ hill people, a harmless agricultural tribe, speaking Tamil, and not apparently materially different from the Tamil inhabitants of the plains, from whence they doubtless came. 'They have several villages and a considerable amount of cultivation on the plateau and its lower slopes. In every village there is at least one temple-cromlech, constructed of slabs with one side open, usually under a tree, containing a crowd of lingam-stones, splinters of rock or long pebbles, mostly

* In Tongataboo the officers of H.M.S. "Calliope" met with a monument "resembling the larger gateway stones of Stonehenge."

+ Close to Bangalore there is an ancient temple approached by a magnificent avenue of trees, beneath which there is a number of small hut-temples, so primitive as to consist only of three upright stones with a superincumbent slab on the top, and inside a rude effigy of a deity carved on the stone forming the kack. 


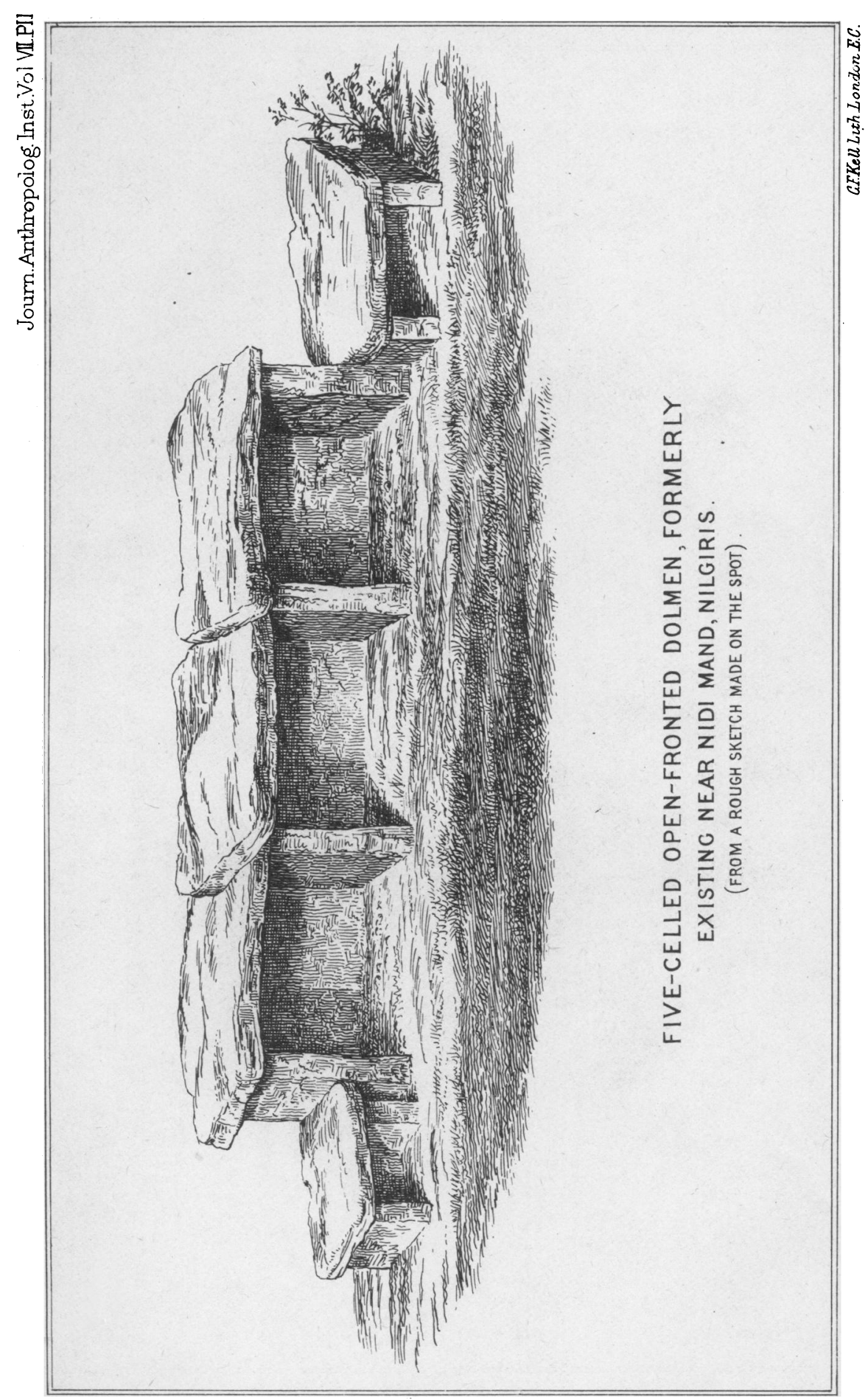




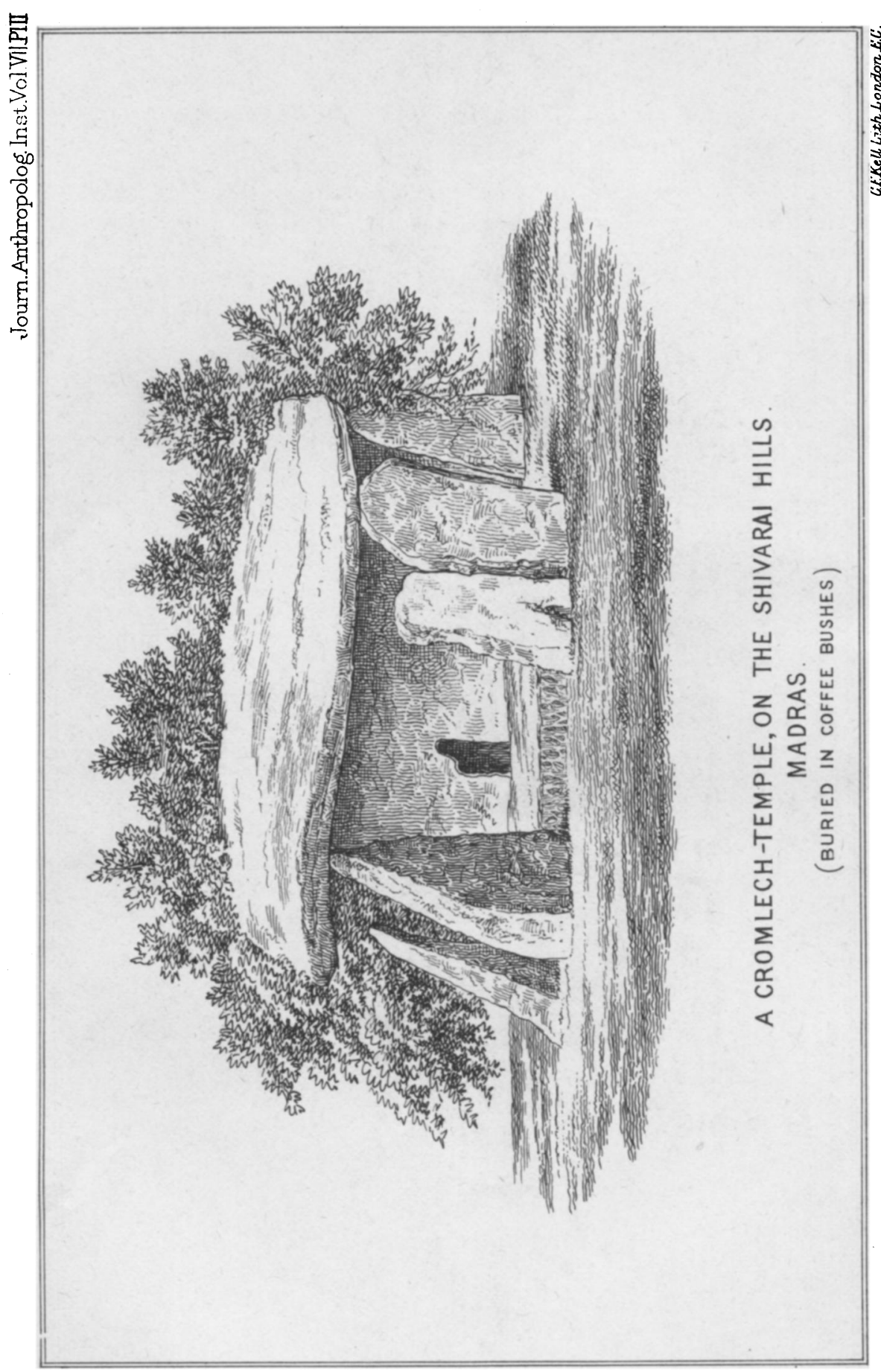


tipped with red paint, and occasionally a small image. In two places I saw a collection of eight or nine of these primitive temples arranged in a semicircle under a huge tree. The crowd of stones in them has a curious appearance, for the people appear especially to choose any of unusual description : splinters of milk-white quartz or black serpentine, water-worn pebbles of various colours, any long piece of stone or pebble that particularly catches the eye, seems to have been picked up and added to the collection. Pieces of petrified wood, and what is most interesting, often quite a number of regular celts, examples of which may be seen in Col. Lane Fox's collection in the Bethnal Green Museum. I regret not having ascertained whether there was any particular name or idea associated with the celts. A rough sketch of one of these rude stone temples is annexed: in the centre there was a large splinter of black stone surrounded by some dozens of small pebbles, all tipped with paint, which is renewed on particular occasions; flowers, boiled rice tinged yellow with turmeric, and fruits are laid before them. Much further to the north, amongst the aboriginal hill tribes of Rájmahal, like structures and worship appear to be used. The Rev. Mr. Christian reports that "a large black stone in an enclosure like a hogsty (which must mean one of these cromlech-shrines), is a principal object of their worship."

Experience indeed seems to show that open-sided structures of the above class were mostly free-standing and non-sepulchral, whilst cromlechs closed on all sides are tombs invariably containing signs of interment, and appear to have been always originally covered by a tumulus. Open-sided dolmens of the former class, though frequent in Wales and Cornwall, are rare elsewhere in England. Of the half-dozen or so recorded I have seen that by the Roll-right stones on the Warwickshire and Oxfordshire boundary, that at Drewsteignton in Devonshire, called locally the Spinster's Rocks, and Kit's Coty house, near Aylesford, known probably to many present. None of these seem to me to have been. sepulchral or ever covered by a tumulus, and I have never heard of anything having been found in them betokening interments. The difference between them and the great chambered graves at Uley, Stoney Tittleton, in Somersetshire, and in Truernsey, which I have also inspected, is very obvious. Though Kit's Coty House is commonly called Horsa's Grave, and that chieftain was doubtless buried in the neighbourhood, Professor Stephens, of Copenhagen, considers that Bede's description of his monument, "Monumentum sub nomine insigne," rather suggests a standing stone carved with his name.

On the Nilgiri Hills, in Madras, there is a large number of 
open-sided dolmens of this class, several of which present the special peculiarity of being sculptured inside with hunting scenes, processional groups, and figures commemorative of Satis or widow immolation. Usually a large dolmen so sculptured is surrounded by smaller plain ones, and consists of a single cell, or sometimes of two, three, four, or even five in a row. In the "Journal of Anthropology, No. I, p. 43, Major Ross King describes a two-celled sculptured dolmen, found by him on the southern edge of the Nilgiri plateau, as having the whole interior, that is to say, the inner face of each slab, covered over with carving; and this is a rough sketch of one discovered by myself, which has, however, been subsequently thrown down and destroyed to make way for coffee planting. It consisted of three large central cells with a smaller at each end; the middle cells were roofed with large covering stones overlapping one another at the edges, and the supporting slabs were covered within by rudely sculptured hunting and processional groups. Nothing denoting an interment has been found in any of these dolmens, whether carved or plain, though burial cairns of another type are abundant on the hills. The various Nilgiri tribes, who have been sufficiently often described before this Institute, lay no claim to them, and regard them with diverse feelings of superstition. Thus the Todas will not touch a sculptured dolmen, and the Bădăgas, the most numerous and recent of the hill tribes, have turned them into deities, not looking on them as temples, but as actual gods; and when it was attempted to remove some of the carved slabs for a museum they petitioned strongly against the proceeding, saying, "It is our God." Nevertheless it is certain that they who are known to have migrated to the Nilgiri from Mysore, three centuries ago, neither raised the dolmens nor sculptured the stones, any more than the Todas, who will not touch them; and whether the builders of the dolmens also wrought the carvings is a debatable point. The latter are distinctly Hindu, and bear allusions to the Băsăva creed, which originated about nine centuries ago. It may be that fugitives from the plains below, in those ages of which nothing is known but that they were filled with wars and turmoil, may have made those carvings on the stones of the temple-like structures they found standing, but the whole point is doubtful. At any rate there is nothing to connect them with burial purposes ; no vestige of urn or interment was discovered in the five-celled dolmen found by me, but in one of the large compartments, in which a man could easily sit, there lay a long piece of polished leg bone, which the people with me said had been put there by the $\mathrm{Ku}-$ rumbars to denote a deity. That dwarfish half wild jungle race, which with their near relatives the Irulas ( $=$ "children of 
darkness ") inhabit the most secluded densely wooded fastnesses of the mountain slopes, are to my mind not the least probably connected with the aboriginal builders of these monuments. Some threads of connection still exist. The Kurumbars of Mulli, one of the wildest Nilgiri declivities, come up annually to worship at one of the dolmens on the table-land above, in which they say one of their old gods resides. Regarded with fear and hatred as sorcerers by the agricultural Bădăgas of the table-land, one of them must nevertheless at sowing time be called to guide the first plough for two or three yards, and go through a mystic pantomime of propitiation to the earth deity, without which the crop would certainly fail. When so summoned the Kurumbar must pass the night by the dolmens alone, and I have seen one who had been called from his forest-dwelling for the morning ceremony, sitting after dark on the capstone of a dolmen with heels and hams drawn together and chin on knees, looking like some huge ghostly fowl perched on the mysterious stones.

Both the Kurumbars and Irulas, when one of them dies, have a custom of depositing a long water-worn pebble (devva kotta

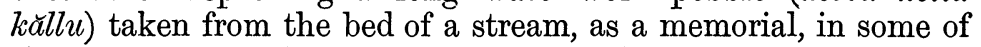
the sculptured dolmens. One large dolmen at Melkundah, in particular, was found filled up to the capstone with these pebbles, which must have been the accumulation of generations.*

Still pursuing the subject of open-sided dolmens, Colonel Meadows Taylor reports that they abound in Sorapur in the Deccan, " open at one side, and formed of three large slabs for walls, and one for a roof. All such cromlechs I have seen are empty." Intermixed with them, however, are numbers of "kistvaens smaller than the cromlechs, constructed on the same

* In Brahman funeral ceremonies there is a usage curiously recalling this custom of a primitive outcast tribe, and perhaps retaining some vestige of stoneworship. After a Brahman's body has been burnt, there are ten days' mourning; on the third day the relations and friends re-assemble at the burningground and, after the bones and ashes have been gathered, a small bank of earth is thrown up, on which three stones are set, one called by the name of the deceased, another by that of Yama, the Lord of Hell, and the last is called Rudra, the causer of tears. The three stones are decorated with flowers, and a sacrifice offered them amid mich lamentation. The leader of the funeral then takes the three stones home with him, and on the tenth day, after other ceremonies have been gone through and the stones again worshipped, the leader takes them, and going into water up to the neck, turns towards the sun and addresses it thus: "Up to this day these stones have represented the deceased; henceforth let him cease to be a corpse; be he now received into Swarga: there let him be happy as long as Ganges shall flow." Saying these words, he casts the stones behind him, and returns to the bank; so the mourning ends. Another allied primitive practice is that of the Kharrias, a very wild jungle tribe of Singhbum in Bengal. This people, after a death, set up a tall rough slab of stone close to the house, to which, as representing the deceased, they make daily oblations. 
principle, but closed on all sides. Generally a circular hole exists in one of the sides." These closed and holed dolmens always contain interments. Here the same principle obtains of open-sided dolmens showing no sepulchral character, and never having been covered with a mound; but it is peculiar that in this instance the closed and holed sepulchral dolmens elsewhere, originally at least, subterranean, stand mixed with the open class, and cannot have ever been underground. This is accounted for probably by Colonel Meadows Taylor's remark that " the whole of the ground covered by the erections is rock, into which the slabs have been fixed, resting upon the rock." Some unknown cause may have influenced the choice of such a spot, the nature of which made it impossible to construct the sepulchral chambers underground. In the mountainous province of Coorg closed and holed kistvaens, sunk underground and filled with sepulchral deposits, are also abundant ; but there is one remarkable group which shows no sepulchral character. Near Somawarpettah, on the rocky summit of a hill commanding a fine prospect all round, there are four large cromlechs, not closed, but consisting of huge overlying slabs supported by masses of stone. The largest slab is 11 feet 8 inches long by 8 feet wide. Each cromlech is surrounded by a circle of stones, stands out in high relief on the hill top, and has never been covered with earth. They were quite empty; nothing connected with interments could be found in or about them, and their appearance is certainly suggestive of altars. Somewhat similar to these is a cromlech at Pallicondah, 12 miles from Vellore, in the Madras Presidency, the one single free-standing dolmen, with no kistvaen or subterranean character about it that I have seen or heard of on the plains. A figure inadequately representing its massiveness and actual appearance will be found at page 491 of "Rude Stone Monuments." The capstone is 12 feet long by 8 wide, and about $2 \frac{1}{4}$ thick, and supported, not by slabs, but by six large rounded boulder-like masses of granite, two at the north end, two at the south, two smaller, not touching the capstone, on the west side, and the east side open. The capstone is elevated about 5 feet from the ground, and on its upper centre were four round depressions, placed

thus, o o, that to the right being smallest. Mr. Fergusson 0

speaks of it as "a sepulchral mound," but it gave me no such idea, for it stands upon a granite platform that rises above the soil, with no means for interment beneath. Open-sided dolmens perfectly corresponding with the Indian and European examples are also abundant in Palestine upon the east side of the Jordan. Mr. D. Robertson Blaine describes them in the "Athenæum" as 
all formed on the same plan. "Three slabs of unhewn granite are fixed perpendicularly in the ground, closely and at a right angle to each other, thus forming three sides of a square. Upon these a fourth slab is laid, overlapping its supports, the south-east side always left open; the supporting slabs about 6 feet high, the top slab an irregular square of about 12 feet." No excavations appear to have been made, but judging from analogy they are not sepulchral. The Arabs call them - Beit el Ghûl = House of the Ghoul, and are terribly afraid of the spot.

The peculiar class of megaliths called "demi-dolmens," in which one end of the capstone always rests on the ground, also has no discoverable connection with interments.* The only example I have ever seen is one on the north coast of Jersey. Captain S. P. Oliver ("Journal of the Ethnological Society of London," vol. ii, p. 66, New Series), speaks of it as " a doubtful demi-dolmen in the northern part of Trinity parish, called the Roche à la Fée," which he was unable to visit. It is on a rocky point of the high cliff between Petit Fort and Vicard Harbour, a beautiful and commanding spot overhanging the sea. The stone is of irregular shape, enormously large and ponderous, 5 yards long, $4 \frac{1}{2}$ broad, and about $2 \frac{1}{2}$ in greatest thickness, and whereas all the other prehistoric remains in the island are of granite, this only is of a pudding-stone formation prevalent in the north-east part of the island, and it has no conceivable sepulchral connection. Another Jersey antiquity is spoken of by Captain Oliver in the same page, thus : "There is some rumour of a trilithon, called the Pré des Trois Roches, having existed close to the sea at St. Ouen, but I could find no trace of it." Indeed it is no easy matter to discover it. I was hunting for it more than half a summer's day in 1860, and found it at last in a field called Pré des Trois Roches, about 500 yards S.E. of the piece of water called St. Ouen's Fishpond. The two standing stones are thick and stumpy, nearly 5 feet high; a third stone, of the same apparent size, lies close by, on the north, flat, embedded in the ground. This megalith also seemed to me non-sepulchral.

I would venture to say little upon stone circles. The far larger proportion of them is undoubtedly sepulchral. Of course all that enclose tumuli or tomb-chambers are. Mr. Fergusson holds that all circles up to 1.00 feet are sepulchral; when they become larger, consisting of stones rising several feet above the surface, and enclosing no form of grave, they may possibly have been devotional. Of examples known to me, I cannot but agree

* It is now asserted, apparently with reason, that these megaliths are only dilapidated dolmens that have lost some of their supports, and have no claim to be regarded as a separate class. 
with the late Rev. C. H. Hartshorne, F.S.A., in considering the large circles on Corndon, on the Shropshire and Welsh border, as having rather a religious application: nothing, I believe, has been discovered in them denoting burials (see "Salopia Antiqua"). The fine circle, too, on the border of the Dartmonr, on the bank of the Teign, above Chagford, seems to me nonsepulchral. On the Nilgiri hills, on the north declivity of the highest summit, on a spot of exceeding picturesque beauty, where several wooded slopes converge, there is a double circle, 35 feet in diameter, of stones of rather small size, none exceeding 3 feet above the ground, except two, which form an entrance on the south side. The stones are placed rather close together, and the inner and outer rings are a yard apart. No trace of an interment has been discovered in this circle, the only one of the kind known to me on those hills. The Irŭlas previously referred to have, however, two temples on the top of Rangaswami Peak, the highest eastern Nilgiri summit, where they twice a year worship Vishnu under the name of Rangaswami, with much ceremony. The temples are circles of rough stones, each enclosing an upright stone that represents the deity. One of the circles is of recent date. The Rev. Henry Baker, of the Travancore Mission, informed me that though tumuli and kistvaens abound on the Travancore Hills, in the extreme south of India, he had only seen one stone circle, much dilapidated, and that it contained no marks of interment. The natives called it a Râshi hill of Parasurāma, from a tradition that when Parasurāma (Rama of the Axe) created Kerala (the long strip of seaboard between the Western Ghauts and the Indian Ocean), rolling back the waters, he sowed the new land with räshies (the small spangle-like gold Hindu coins frequently found all over the country), and buried the surplus in this circle. The "Athenæum" of 31st May, 1851, reported that Sir Robert Schomburgk had discovered in St. Domingo " a granite ring, 2,270 feet in circumference. In the middle of this circle lies an idol, nearly 6 feet in length, formed likewise out of granite. In all his travels in Guiana or the continent Sir Robert never met with such a monument." This too appears an instance of a devotional circle.

It may not be out of place to conclude this paper with some instances of worship and observances, unconnected with funeral rites, paid to rough stones anciently and at the present day. Pansanias expressly affirms (Lib. vii, 22) that in the most ancient times, universally amongst the Greeks, rough stones

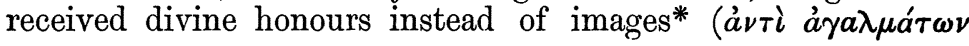

* Lucian (de Deâ Syriâ) affirms that the Egyptians first attained knowledge of divine things and built temples, which the Assyrians learnt from them, but 


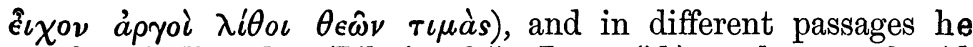
speaks of Hercules (Lib. ix, 24), Juno (id.), and even Cupid (Lib. ix, 27) and the Graces (Lib. ix, 33), being represented by rough stones " according to ancient usage." Apollonius Rhodius II, 1172, speaks of a great sacred stone in the temple of Mars at Orchomenos, worshipped by the Amazons. The pre-Mahometan Arabians were especially stone-worshippers, Maximus Tyrius, who says he saw it, affirms their idol was only a square stone, whether hewn or rough is not clear. Suidas says they worshipped the planet Mars at Petra under that figure. The ancient Laplanders worshipped rough stones called Seiteh. The Israelites are warned against " setting up any image of stone in their land to bow down to it" (Levit. xxvi). The "image of stone" (Heb.

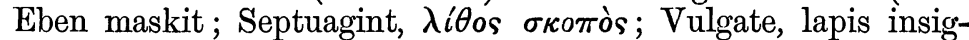
nis) may have been a rough stone pillar, perhaps a phallic emblem. Up to the 9th century A.D., there were several decrees of Councils and kings against popular stone-worship, evidently not of images, but of rude stones (saxa-lapides.) I think it not impossible one such stone may still be seen. In Devonshire, in the Chagford Valley, under the Kestor and the mysterious stone avenues, and not far below the meeting of the North and Sonth Teign, there is a great stone, famous locally as the Puggie stone. It stands in a fairy-haunted spot above the wooded hollow down which the Teign rushes from the Dartmoor heights, and is a large rock-boulder 12 or 15 feet high, and little less in breadth. The outer side is plain, but on the inner side facing the river, there are natural rifts and hollows, so disposed as to give some idea of a gigantic human face, and grotesquely indicate eyebrows, nose, and mouth. On the top of the stone there is a large and regular rock-basin. Many stories cluster about the spot, and the name, Puggie Stone, is evidently derived from Pouke, the old term for a demon or evil spirit, whence too Puck. Cromlechs in the Channel Islands are still called "poukelays." Possibly in prehistoric ages when the hut-dwellings, stone-circles and avenues on the Dartmoor above were inhabited and the scenes of unknown rites, this strange-looking stone may also have been worshipped, and regarded with an awe that reached far into Christian times, and is hardly yet extinct. The names of many places may also contain traces of stone-worship. In France

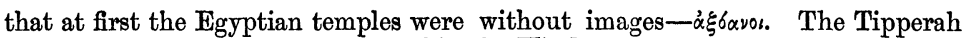
hill-tribes in Bengal, who now worship the Hindu gods, say that before the reign of the legendary king Trilochun, they worshipped no idols, but objects of nature, such as stones and trees; and amongst the Oraons, another Bengal forest-tribe, Chanda is the god of the chase always invoked before hunting. Any piece of rock, or stone, or excrescence on a rock, serves to represent this deity; for the Oraons must have something material to worship, and their most popular demon, Darha, is represented by a ploughshare set up on an altar.-(Col. Dalton).

VOL. VII. 
several towns bear the name of Pierre Fiche, which means an unwrought tall stone-a menhir.

One source of the veneration paid to stones may have arisen from their use as land-marks or memorials of agreements"stones of witness"- such as the pillar set up in witness of the compact made between Jacob and Laban, along with the heaps, in the passage of Genesis already quoted. Such, too, was the "Great stone" set up by Joshua under an oak before the Sanctuary of the Lord, "to be as witness unto us," and the Ebenezer stone set up by Samuel between Mizpeh and Shen. Herodotus relates that when two Arabians made a compact, they cut the inside of their hands with a sharp stone and rubbed the blood upon seven stones ranged between them. Amongst the Khasia hill-tribes of India, "when there was war between Cherra and Mausmai, they made peace, swore to it, and erected a stone as a witness."-Mausmai = Oath-stone. A promise made on the Odin-stone in the Orkneys was within living memory the most inviolable of engagements. On passing the Jordan 12 stones were set up in the midst of the river and 12 in Gilgal, as a memorial, by command of Joshua, and it is possible that " they are there unto this day." In Ramnad, Southern India, there are nine stones on the sea-shore, said to have been planted by Rama on his expedition to Ceylon to represent the planets, and worshipped by him ; they are emblems of prosperity to the country; any of them breaking off or crumbling at the top is an omen of disaster. It is not difficult to conceive how stones placed for any of the purposes just enumerated would attract sentiments of awe and veneration.* Oil would be poured upon them, and they would become anointed stones, such as may be seen to-day by every road-side in India. $\dagger$ Jacob both after his dream, and after he had talked with God, set up a stone and poured oil thereon. Theophrastus in his "Characteristics of a Superstitious Man," says, " if at crossings he should see an anointed stone, he falls upon his knees, pours oil upon it, and worships it." Lucian, too, in his "Pseudomantis," says of Ruti-

* Such sentiments would be increased when, as would not unfrequently happen, magical or healing virtues became attributed to the stones. Geoffrey of Monmouth, in a well-known passage, tells a legend that when Aurelius consulted Merlin as to what monument should be raised to the Britons treacherously massacred by Hengist, the enchanter replied, "You would have the giant's dance brought from Ireland! Do not, Lord king, vainly excite laughter; those stones are magical, and virtuous in healing in many ways; giants brought them of old from furthest Africa; they heal sickness and cure wounds; every stone there has its own healing power." In France, even to-day, women are said to sit on dolmens to cure sterility. In the West of England, almost up to recent times, children were passed through holed stones for various diseases; and the Welsh Triads affirm that "on the stones of Gwiddon-Ganhebon one could read the arts and sciences of the world."

+ This consecration by oil is in India termed Nivêdyam. 
lianus, that he was an excellent man and of noted valour in war, but very superstitious in religious matters, so that if he saw an anointed stone anywhere he would fall down and adore and offer petitions to it. These passages show that rough stones were commonly venerated in classic times. In France to this day the inhabitants of the Haute-Loire are said to anoint with oil the " peyro martino" of Livernon (a dolmen figured in " Rude Stone Monuments," p. 347), as in ancient times. Anointing rocks and stones with oil turns them black, and this may be one reason for the particular veneration paid to black stones, as well as that being the usual colour of aerolites, the fall of which on a large scale is a startling phenomenon, certain to excite strong superstitious awe amongst all primitive and ignorant peoples.* Captain R. J. Burton, after kissing and handling the famous Black Stone of Mecca, was convinced it is an aerolite, and so probably was the Phœnician Image of the Sun, called Elagabalom, which Herodian says was worshipped by all the neighbouring kings, and was a large black cone-shaped stone said to have fallen from the sky. It is curious that the Ayeen Akbari (Life and Deeds of the Emperor Akbar) mentions a pillar of black stone, 80 cubits high, as the most sacred object before the Temple of the Sun at Jaganath, and the idol is described there by Captain Hamilton as a huge black pyramidal stone. $†$ The ancients called aerolites Bœtylia, and held them mythically to be the stones palmed upon Saturn by Rhea for his children, and vomited up by him. Hesiod in his Theogony mentions a famous sacred stone in Pytho under the heights of Parnassus, said to have been the stone palmed upon Saturn for Jupiter, and to have been planted in Pytho by the latter for a wonder to all men, probably some legend of a great meteorite. Other instances of black stone worship are the idol of the mysterious Siaposh in Central Asia, which Mr. Masson describes as " an erect image of black or dark coloured stone the size of a man." The Hermansäule of the Germans seems to have been in its earliest form a tall black stone. Captain J. Cope, who travelled through Western India in 1758 , describes a ceremony he saw in "a certain grove on the coast of Canara, when several thousands of

* In February, 1857, at noon, two aerolites fell in the district of Madura, Madras Presidency; they fell about three miles apart, with a tremendous reverberation like prolonged thunder, but much louder, that was heard at a distance of 40 miles ; one weighed $37 \mathrm{lbs}$. , the other was four times larger; they struck cultivated ground and buried themselves more than two feet in the earth: one of them is now in the British Museum. The natives in the neighbourhood, when they fell, dropped on their faces and remained long prostrate with fear; afterwards great crowds came and worshipped them. In some temples in Bengal the lingam-idol is said to be a meteoric stone.

+ Antonio de Solis relates that a large black stone was placed before the idol on the pyramid of the great Mexican Sun-temple. 
people assembled, and in the middle of the grove was placed a black stone of 300 or $400 \mathrm{lbs}$. weight, without any designed shape, but bedaubed with red lead mixed with oil. A little earthen pot of fire was placed before the stone, and a girl about ten years of age to attend it." This was probably Vetâl, an aboriginal Bhuta or Demon; his usual image is a rough pyramidal stone from 2 to 4 feet high, generally under a tree on the east side, and sometimes surrounded by a circle of stones which typify his retinue of attendant demons. It has been previously stated that the Râjmahal hill-tribes worship Raxi under the form of a black stone, and Col. Dalton (Ethnology of Bengal) reports that when a man-eating tiger infests the village, or a bad epidemic breaks out, Raxi has to be sought out, and with the aid of a priest or diviner, a black stone, which represents the god, is found, and set up under a large tree. Châl or Châlnâd is similarly sought when any calamity befalls a village, and he also is found as a black stone, and set up under a Mukmum tree.

At the present day the most sacred amulets among the Hindus are the Sâlagrams, black, smooth, water-worn ammonites brought from the Gandak river in the Himalaya, and carried all over India ; they are held to typify Vishnu and all the gods. The shepherds of Languedoc are said to carry black stones pierced with holes as an amulet to preserve their flocks from the rot.

Indeed, rude stone worship exists to-day perhaps to an unsuspected extent. Mr. Masson relates that in the temple dedicated to the goddess at the foot of the Koh Assa Mahi (Hill of the Great Mother) near Cabul, " a huge stone is the object of adoration." Major Macpherson states that " a special deity of the Khonds is a stone without shape, and weighing about 75 lbs." Nadzu Pennu, the village god, and Koda Pennu, the horse god, are represented also simply by stones placed under a large tree. Southwards, in the Peninsula, a large proportion of the agricultural and forest castes represent their deities by rough stones. One instance is noteworthy as showing on what occasions, and how easily, a new god may be set up amongst a primitive people. The late Mr. Breeks in his "Wild Tribes of the Nilagiri Hills," relates that a few years ago the Kôtas, one of the tribes of the Nilagiri Hills, were visited by a virulent disease which carried off so many of them that the village was abandoned. As they are the ironsmiths of that region, their neighbours, the Badagas, probably found their absence inconvenient, and a Badaga passing one evening by the deserted village, received a mysterious communication from something in the shape of a tiger, that unless the Kôtas returned the disease would spread; so they returned. Now their only previous deities were Kāmatarāya and his wife, each represented by a thin silver plate, but now they set 
up a new god, an upright stone, and called it Māgāli, whose special office was to protect them from the disease, which did not appear again ; and every year since goats and fowls are sacrificed to Māgāli. It has been already mentioned how another tribe, the Irulas, worship Rangaswami under the figure of an upright stone in a circle on the easternmost Nilgiri peak; they too of late years have added another circle and stone to the old temple, and call the latter Great, and the former Little, Rangaswami. Lower on the mountain slopes the still wilder Kurumbas worship a rough round stone under the name of Hiria Deva, $=$ Old God, setting it up either in a cave or irregular circle. I will add a few more instances of existing stone-worship in those provinces most familiar to me. In Mysore when a new village is founded, the principal Gowda, or head-man, places a large stone in or near the site, called Kŭrŭvu Kallu, or Calfstone, this represents the tutelary village god, and receives annual worship and offerings. In the same province the Goalâr, or herdsmen, have a small temple containing two shapeless stones termed Jinjappa and Râmappa. The Beidâru, who are cultivators, worship a rude shapeless stone placed on a cairn, or sometimes in a cavity of a rock. The iron-miners have a deity named Mûti Rāya, = Pearl King, a shapeless stone placed in an open-sided dolmen about 6 feet square. Another caste that cultivates betel-leaf gardens has two deities, Sidday devāru, a stone set up in a betel-vine garden, and Urukăti, a stone placed in a wood.

In Malabar the goddess of the salt-makers is Nidamah Bhagavati, a stone placed in a cocoa-leaf hut; that of the Poliars, a degraded slave-caste, is Paradēvata, a rough stone placed on a mound in the open air. The goddess of the Pariahs is a stone placed in a small hut, called Mâriti ; and of the $\mathrm{Ku}$ rumbălar, a stone named Madya dêvam, planted on a heap of pebbles. In Coimbatore the Pallies, a numerous caste, have two special deities, Mānār Swāmi and Pachamma, both large stones ; the Maleiărăsar, = Hill-kings, commonly called Mulsers, of the Anamalay and Paulghaut jungles, have a god named Mallang, who is a stone surrounded by a low wall, and the Kāders, = forest men, who live in the depths of the forests, have a male god Mudeviran, and two female deities, Pey-kōti Amma and Kali Amma, all represented by rude stones placed in small huts. All these obscure deities receive bloody sacrifices, i.e., offerings of fowls, goats, or sheep, ${ }^{*}$ but it must not

* Mr. Horne, however, informed me that in Himalayan villages a stone is set up as a pillar in the centre, the top smeared with whitewash, and five fingermarks of red ochre laid on, and on this flowers are offered for the prosperity of the field. 
be supposed that they absorb the worship of the several castes and tribes enumerated; many worship the ordinary Hindu gods as well. The instances just given are but from a very small part of India, and the list might doubtless be immensely increased, proving the wide prevalence of stone-worship there today. Mr. Hunter in his work "Orissa," vol. i, p. 95, observes of this two-fold worship, "At the present hour in every hamlet of Orissa the common people have their shapeless stone or block, which they adore with simple rites in the open air; while side by side with it is a temple to one of the Aryan gods, with its carved image and elaborate rites." So in the early ages in Europe, the rude stones of popular worship doubtless stood long by the first Christian churches. In our stage of intellectual advancement it is difficult to put ourselves in that mental posture which could directly and literally worship " stocks and stones." One may conceive how prayers and adoration might be offered to the statues that embodied the ideals of majesty, intellect, and beauty in old Greece, and imagine the stern unimpressionable Roman Consul shrinking abashed before the Zeus of Phidias, in Elis, exclaiming that he beheld God! We know how widely over Europe images are regarded with feelings approaching adoration, and can conceive how the hideous idols of the South Seas inspire a worship prompted by superstitious dread, but it does not seem so easy to comprehend how mere rude stones-shapeless masses and splinters of rock-could be taken to symbolise, or to be, a deity. Animals, terrible, useful or beautiful, trees, flowers, striking natural features, might suggest ideas of awe or veneration, and indeed vestiges thereof survive amongst civilised peoples, as well as amongst those tribes that most nearly represent the prehistoric races, who were presumably alive to the same influences. Still it is hard to think why dull lumps of stone and rock should be chosen as emblems of any supernatural power, yet the fact remains that a collection of lumps and splinters of stone by the wayside suffices for Hindu worship to-day, and might have sufficed for the men of the stone ages.*

* Another cause of stone-worship may be the influence of old legends. Amongst the feats of the god Siva, it is recorded that being angry with the six nurses of his son, Kartikeya, because they were careless in learning the eight forms of prayer, he laid on them a malediction "that they should become large stones under the Banyan tree near Madura, for 1,000 years." Whilst undergoing this penance, they were worshipped as evidences of the power of the god. Megaliths in Europe are often popularly held to be transformed men; e.g., the Rollrightstones and the Cornish hurlers. Again, at the foot of a mountain in Travancore there stood a magnificent and gigantic timber tree : four men with outstretched arms could not compass its trunk. Several rude stones of no great size placed at its base had been worshipped from time immemorial and supposed to represent forest-gods who dwelt in its branches. It was the blood and ashes and other 
There could be nothing in this of that nature-worship so largely developed in modern poetry and philosophy, of which Wordsworth has been the great hierophant. Neither living savages nor men of the flint days can be thought of as finding sermons in stones, or thoughts that lie too deep for tears in a flower or tree ; and Kingsley's apostrophe-

I cannot tell what ye say, red rocks!

I cannot tell what ye say,

But I know that in you too a spirit doth dwell, And a word in you this day!

would be taken by them in a very different sense. Such ideas indeed are the latest result of culture; and to a higher plane of mental perception and reflection also would seem to belong that idea of generation, symbolised in so many ancient myths and religions by the pillar, spire, lingam, circle, cave, \&c., of which rough stones might be the readiest emblems, and so become sacred.

Were any clue possible to the dark labyrinth of prehistoric thought, it might be looked for amongst the most secluded, uncultivated races, such as are described by the Rev. W. W. Gill ("Myths and Songs from the South Pacific"), in Mangaia, the most secluded of the Society Islands. One idea pervading Mangaian mythology is that earthly objects are but the material bodies of spiritual powers or originals, so that if an axe cleaves or a club kills, it is because demons are invisibly present in them; and the idea extends to supposing that all ordinary inert objects have spiritual doubles, or ghosts.* Thus when Indians bury a warrior with all his weapons, it is with the idea that the ghosts of the weapons may go with his to the Spirit-land. This helps us to conceive how tribes in India to-day can see deities in shapeless stones; so may it have been with men in the unknown prehistoric past, in whose graves, too, weapons are so frequently found, deposited perhaps with the same idea. Another

manure deposited there on sacrificial and festival occasions that had nourished and so wonderfully enlarged this colossal tree. The missionaries wished to purchase it for the erection of a large chapel at Neyur, and after obtaining permission, were obliged to call Christian workmen from a long distance to cut it down, all the mountaineers refusing to assist, and viewing its felling with great alarm from a distance. All the woodwork of the new chapel was made from this single tree, and the forest-people afterwards listened more readily to the preaching of the missionaries. An occurrence like this in recent years probably represents many similar passages in the early centuries of Christianity in Europe.

* The idea underlying the primitive Vedic religion is that material objects have a spiritual as well as a physical potency, and may thence be addressed with prayer and hymns. So, too, Swedenborg's famous Doctrine of Correspondencies declares that all physical things are but the types of things existing in the spiritual world. Even so rude a people as the Karens of Chittagong, have an analogous idea; every object amongst them has its kelah, or genius; if the rice crop is unpromising, its kelah has to be invoked. 
aspect of the same primeval way of thinking seems to exist in the Gaûri, the most popular and universally observed festival, except one, in India. It is held in the beginning of September, when people of all castes and classes, from the Brahman to the Pariah, offer prayers and sacrifices to the tools and implements used in their several professions and crafts. Learned Brahmans and well educated clerks and officials put together their writing materials, paper or palm-leaves, pens, stylus, and ink; the merchant and bazaar man their account books and scales; the cultivator his plough, hoe, and harrow ; the carpenter and smith their tools; the weaver his loom and shuttles; the tailor his needles, \&c.; the barber his razors and hone; the women their baskets, rice-pounders, pots, and household implements, and placing flowers and incense, prostrate themselves at length before the objects of their daily use, with thanks for having afforded the means of living, and prayers that they will continue to do so. This worship is offered directly to the things themselves, and not to any deities symbolised,* and seems to contain the germs of the South Sea theory, and suggest how worship can be paid to "stocks and stones," whether in prehistoric or present times. More than the men of Athens, the Hindoos are $\delta \epsilon \iota \sigma \iota \delta a \iota \mu o \nu \epsilon \sigma \tau \epsilon^{\prime}-$ po (Acts xvii, 22) in the true sense of greatly prone to recognise the presence of supernatural powers; and men versed in English literature, in law, and moral philosophy can roll up little balls of cow dung and clay, give them divine names, worship them, and toss them aside. This disposition may have begun far back in prehistoric times. Some have held that religious sentiment was then a blank, arguing from certain tribes among whom travellers have reported no appearance of religion existed, but it is always questionable whether they had penetrated all the modes of thought about them. That sentiment must have originated some time, perhaps not very long after passing from Darwin's tailed arboreal stage, and rough stones might have been, and continued to be, as now amongst so many primitive tribes, the readiest symbols of beings imagined out of themselves. Sir John Lubbock ("Origin of Civilisation," p. 205) thinks that stoneworship is " merely a form of that indiscriminate worship which characterises the human mind in a particular phase of development." This, however, hardly explains why rough stones should be so generally selected amongst all natural objects for adoration, but all Sir John Lubbock's pages on the worship of stones demand the highest consideration.

Before quitting this subject, a word may in conclusion be said upon that oldest of historic rough stones now in our midst- that

* There are also two ceremonies conducted by women, in which metal and earthen vessels are converted into gods, and worshipped as such. 
Stone of Destiny brought in days beyond the ken of history from Spain to Ireland as a talisman of national welfare. On it the ancient Irish Kings were crowned, when, if on being smitten it sent forth a clear ringing sound, the ceremony was auspicious. Carried to Scotland, it was long the palladium with which national independence was bound up, and brought thence in triumph, as the most certain token of victory it has for six hundred years rested beneath the Coronation chair at Westminster. The consideration and sacredness attaching to this famous stone in its various shrines and changes are almost a measure of the survival of stone-worship in the West. Were it lost or dragged from its present sanctuary, there would not be the same wide popular dismay that followed its last removals, but I think few here present would not experience a feeling deeper than simple antiquarian regret.

\section{Discussion.}

The President observed that researches such as those of $\mathrm{Mr}$. Walhouse on megalithic structures and stone worship of modern times were well calculated to throw light on the monuments and religious practices of far earlier times. He was inclined to think that some of the stones which were the subject of veneration at a remote date might have been of meteoric origin. The so-called "image" which fell down from Jupiter and jointly with Diana, was the subject of worship at Ephesus, might well have been a meteorite. He thought that the sites of many Christian churches had been determined by the spot where they were erected being already deemed sacred; and the large blocks of stone which were built into the wall of the church as at Le Mans, or lay just outside it as at Trèves, or were still erect in the close vicinity as at Rudstone in Yorkshire, might perhaps be the original rude stone idols which had hallowed the sites.

Mr. Hyde ClaRKe said Mr. Walhouse had made a reference which was perhaps connected with a prehistoric belief which must have been widely distributed. In the Guarani language of Brazil and Paraguay there were separate words for what had life or soul, and what was dead. Thus a distinction was made between the head of a living and of a dead man or animal, and so throughout. Stones would receive worship on two grounds: first, divine stones or meteorites falling from heaven; second, stones as being representatives of natural organs. Mr. Walhouse had well illustrated the parallels between the stone gods of Greece and India. On examining Mr. Ferguson's stone monuments, he had been surprised to find the small evidence of astronomical or symbolical numbers, and this he considered was consequent on the paucity of our recorded information on the subject.

Mr. Lewis thought a distinction should be drawn between such allignments of stones as those of Carnac and Ashdown Park, and 
mere double lines or avenues, such as exist on Dartmoor and elsewhere. Sacrifices were offered before lines of stones in Southern India, and similar lines were erected as memorials in Northern India, and they might therefore suppose that the European allignments were erected for either purpose, as there was every reason to believe that they were not sepulchral. The two slabs with one across forming a shrine or canopy for an image appeared to resemble Kit's Coty House without the central stone, which occupied the place of the image, and it had often struck him that that stone being rougher than those which surrounded and covered it, might have been held in greater respect. The direction to the Jews not to hew the stones used for their altar was well known, and the same idea might have prevailed elsewhere. There were several instances of non-sepulchral dolmens in England besides those mentioned by Mr. Walhouse, and three upright stones, arranged like those of Kit's Coty House, but without a capstone, were found in connection with some of the larger circles. Referring to the black stones pierced with holes mentioned by Mr. Walhouse, Mr. Lewis said some people in England still preserved stones with naturally formed holes, and called them lucky stones; and referring to some remarks by Colonel Lane Fox, he thought he had recently seen it stated that the custom of attaching pieces of rag to certain objects prevailed in Russia. He thought Mr. Walhouse's paper a most useful one, and that the information about the dolmens used as repositories for sacred objects was particularly valuable.

Mr. MOGGRIDGE said, I could have wished to have gone more fully into the subjects treated of in the very able paper which has just been read, and the remarks that have been made thereon; but will confine myself to two points-1st, the hanging of rags on bushes near to some spring or shrine supposed to be of potent power. These I believe to be votive offerings, testifying gratitude for cures whereby those rags were no longer required for dressing the parts affected. This custom prevails extensively, not only in England and Wales, but also on the continent, even down to the shores of the Mediterranean.-2ndly, upright stones. These, whether monumental or not, frequently became objects of worship. On some of them may be seen the figure of a cross, cut by the early Christians, in order that the heathens, while paying their accustomed adoration to the maenhir, might, in fact, be worshipping the symbol of our faith: a pious fraud-but manifesting a kindly feeling.

Mr. Walhouse in answer to the President expressed his opinion that the red marks often placed in India on sacred stones were analogous to the caste marks on the foreheads of Hindus. Every one amongst them must have some mark on his forehead. To have it bare is a sign of being in mourning or unclean, and it is disrespectful to appear so in company. Hence all images of the gods have the forehead carefully adorned with caste-marks, and the custom is extended to daubing stones, or anything sacred, with red. Colonel Forbes Leslie, however (Early Races of Scotland, ij, 464), 
thinks the red marks are intended to represent blood. The author, with respect to tying rags to a bush at a spot where a man had been killed by wild beasts, said he had only met with two or three instances, and believed that the rags were tied to a bush in lieu of stones added to the stone-heap raised at first, after loose stones had become scarce around. In answer to Mr. Lewis, he said that he remembered no outlying stone near the circle described by him on the Nilgiri Hills, but there is a smaller circle at a short distance on the eastern side.

Col. Lane Fox, Mr. Jeremiah and others offered some remarks.

Major Wisden exhibited some bronze antiquities lately discovered in the neighbourhood of Worthing, consisting of palstaves, socket-celts, and pieces of metal. The palstaves, 29 in number, were looped, and those exhibited were without ornamentation on the blades, and in form much like Evans's Petit Album, Pl. IV, No. 3. The socket-celts, 12 in number, were of the type Pl. V, No. 2, and the metal had been cast in cakes, which had subsequently been broken into pieces. The whole had been buried in an urn of burnt clay intermixed with coarse sand, or possibly flint, which had been pounded into small angular fragments. The urn was too much broken for its shape to be recognisable.

The President remarked that the objects probably belonged to the close of the bronze period in this country.

The meeting then separated.

MARCH $13 \mathrm{TH}, 1877$.

John Evans, Esq., F.R.S., President, in the Chair.

The minutes of the previous meeting were read and confirmed.

The following presents were announced, and thanks were ordered to be retured to the respective doners for the same :-

For the Library.

From the SocieTY.-Proceedings of the Royal Society. Vol. XXV, No. 177.

From the SociETY.-Jahrbuch der K. K. Geologischen Reichsanstalt. Vol. XXVI, No. No. 4; Verhandlungen der K. K. Geologischen Reichsanstalt. Nos. 14-16.

From the SocieTY.-Mittheilungen der Anthropologischen Gesellschaft in Wien. Vol. VI, Nos. 6-10. 